\title{
Determinant of Consumptive Behavior: Study on Accountancy Colleger
}

\author{
Suparti, Dodik Juliardi, Mohamad Arief Rafsanjani \\ Department of Accounting \\ Universitas Negeri Malang \\ Malang, Indonesia \\ suparti.fe@um.ac.id
}

\author{
Henry Praherdhiono \\ Department of Education Technology \\ Universitas Negeri Malang \\ Malang, Indonesia
}

\begin{abstract}
The present study aimed at examining the effect of socio-demography (age, gender, working experience, and academic skill) on financial literacy and students' consumptive behavior. This study was conducted on students of Department of Accounting, Faculty of Economic, Universitas Negeri Malang (State University of Malang) with 169 samples by employing convenience sampling technique. The data were obtained through online questionnaires and the data analysis used path analysis. The findings of the study indicated that gender, working experience and academic skill have a significant effect on financial literacy and have an indirect effect on students' consumptive behavior through financial literacy as a mediator variable. However, this study failed to find the significant evidence of age effect on student financial literacy.
\end{abstract}

\section{Keywords-consmuptive behavior, accountancy colleger}

\section{INTRODUCTION}

The rapid development of technology and information facilitate consumer access to information of the goods offered. This is a consequence of globalization and then there are many ways to offer online products by using social media and the other online media. The ease in accessing the information on products offered leads to the consumptive behavior of the society. If this behavior is done excessively then it is not the need that should be fulfilled anymore, but it is the fulfillment of the irrational desire. This case was also confirmed by Lina and Rosyid [1], who stated that buying behavior is no longer based on rational considerations but only based on the desire.

This phenomenon does not only occur at the level of adult consumers, but it can be found at the teen consumer level [2]. Nowadays, teenagers tend to imitate the up to date trends, like the tendency to buy branded goods in the form of communication tools, clothes, watches and the other teen accessories. This case shows that they do not want to be out of date and they are always trying to keep up with current styles or trends.

One of the factors that influence the consumptive behavior is the internal factor, which is learning process [1]. This learning process is an individual's knowledge to understand something. The individual knowledge that demonstrates an understanding of general knowledge of finance, investment, savings and insurance is the definition of financial literacy [3]. Individuals who have a high financial literacy can manage their finance well [4]. Another opinion reveals that individuals who can make correct decisions and determine the priority scale of needs in financial management will not have financial problems (financial distress) in the future [5].

The low knowledge of financial literacy among students is due to a lack of education on personal finance management at the university level [3]. Furthermore, Chen and Volpe revealed the need for further research on financial literacy in students majoring in business/ management and differences of knowledge on literacy in term of gender. In planned behavior theory, the behavior of each individual is influenced by many things such as gender, age, experience and knowledge of an individual. In addition, individual's behavior is also the result of the reasoning process influenced by attitudes, norms, beliefs, and expectations [6], [7].

The factor of age, gender and work experience have a positive correlation with the individual's understanding level of financial literacy [8]-[10]. Furthermore, if gender has a correlation with one's financial literacy, it is revealed that men are smarter in managing finance compared to women [8]. Men are more confident in making financial decisions than women, who tend to be risk-averse [11].

Furthermore, the academic ability of an individual allegedly can reflect the knowledge and ability of an individual in applying information that is known [12]. Hogan et al. [10] found that there is a relationship between academic ability and student's financial behavior. Students with good academic ability, in this case, are indicated by the achievement index, are identified as individuals who have good financial knowledge as well.

Some previous studies only looked at the correlation between socio-demography and financial literacy, but this study, looked at not only the correlation of those things, but also the impact on student consumptive behavior. 


\section{METHOD}

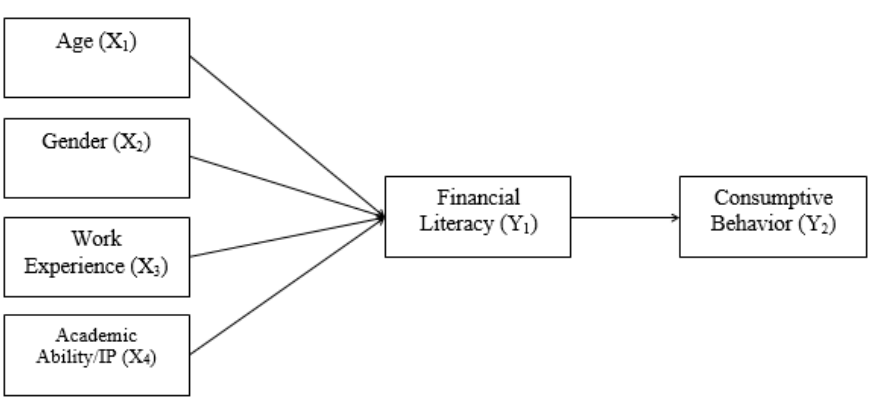

Fig. 1. Relationship among variables

This study was conducted on 169 students majoring in accounting in the faculty of economics, State University of Malang, taken by using convenience sampling technique. Data collection was done by using online questionnaire with the help of google form. The test of direct and indirect influence in this research used path analysis technique. The design of this research is presented in Fig. 1.

The variable of age is the ratio scale that indicates the age of a person. Variable of gender is the nominal scale to differentiate between male and female respondents by scoring 1 and 0 . Variable of work experience is the ratio scale indicating whether the respondent has working experience (how long/ year) or does not. The variable of academic ability is seen from the achievement index (IP) of the respondents. The variable of financial literacy was measured by using OECD financial literacy questionnaire developed by International Network on Financial Education (2011) and Financial Literacy Quiz developed by NFCS (National Financial Capability Study).

The variable of consumptive behavior was measured by some indicators consisting of 8 indicators, namely buying products because of the gifts given, attractive packaging, selfappearance and prestige, price considerations (not the usefulness), status symbols, idolizing endorsers, expensive price causes confidence, and desire to try a product with a different brand.

\section{RESULTS AND DISCUSSION}

The results of path analysis using Lisrel 9.30 Student Edition can be seen at Fig. 2 and Fig.3. From the results of test, then the structural equation can be formulated as follows:

$\mathrm{Y} 1=-0.21 * \mathrm{X} 1+1.34 * \mathrm{X} 2+3.86 * \mathrm{X} 3+2.70 * \mathrm{X} 4$

Errorvar. $=9.99$

$\mathrm{Y} 2=1.71 * Y 1$, Error var. $=120.64$

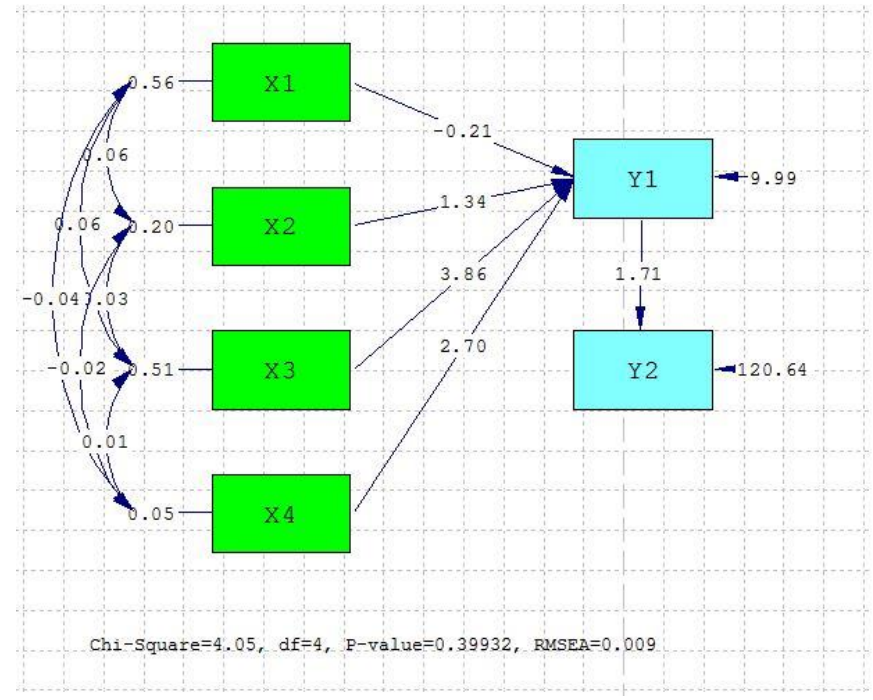

Fig. 2. Unstandardized Coefficients of relationship between variables

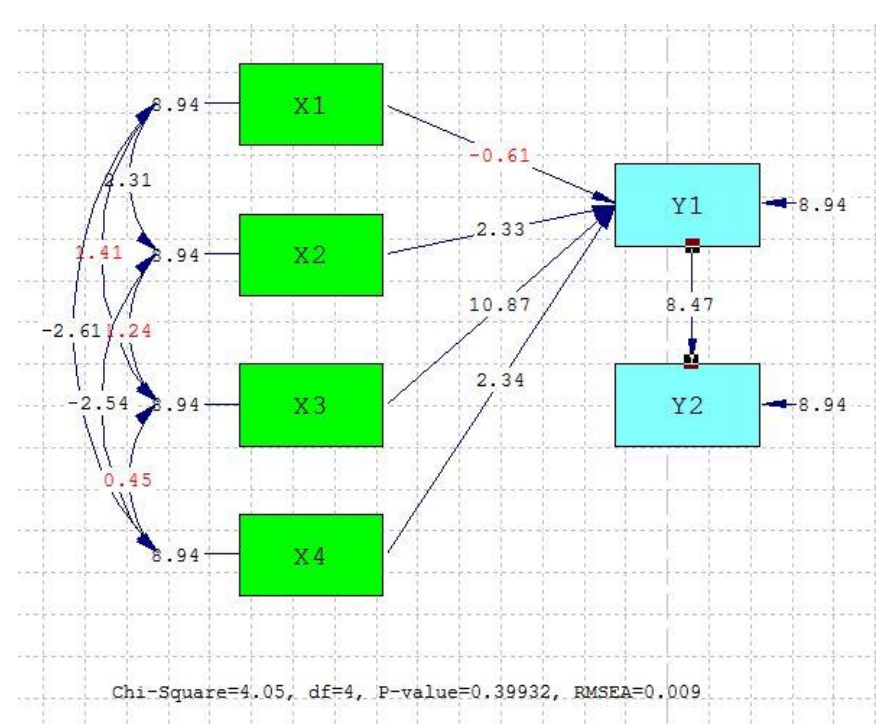

Fig. 3. T-values of relationship between variables

\section{A. Relationship between Age (X1), Financial Literacy (Y1) and Consumptive Behavior (Y2)}

The test results indicated that the variable of age does not have a significant relationship with the variable of financial literacy (t-count $<$ t-table, $-0.61<1.97$ shown at Fig. 3$)$. The results of this study do not support the findings of the previous research conducted by Ansong and Gyensare [8] that a person's age has a positive relationship with financial literacy. The findings of this study indicated that age does not reflect the level of one's financial knowledge. The old person is not a guarantee that he/ she will have more knowledge and financial skill.

The results indicated that there is no significant influence of age on financial literacy, this study could not prove the indirect effect of age on consumptive behavior (through financial literacy), because there was an insignificant pathway lane (X1 $\rightarrow \mathrm{Y} 1)$. 


\section{B. Relationship between Gender (X2), Financial Literacy (Y1), and Consumptive Behavior (Y2)}

The test results indicated that the variable of gender has a significant relationship with variable of financial literacy ( $t$ count $>$ t-table, $2.33<1.97$ shown at Fig. 3). Furthermore, we conducted a different test (t-test), which showed that there are significant differences in financial literacy of male respondents with female respondents. The mean of financial literacy score in this study shows that men have higher scores than women. The results of this study reinforce the findings of previous research conducted by Ansong and Gyensare [8] and Taylor and Wegland, [11] that men are smarter in managing finance compared to women, and men have higher confidence in making financial decisions than women, who are more riskaverse.

The test results indicated that financial literacy has a significant relationship with consumptive behavior (t-count> ttable, $8.47<1.97$ Shown at Fig. 3). The results of Sobel test showed that the influence of gender on consumptive behavior which is mediated by financial literacy $(\mathrm{X} 2 \rightarrow \mathrm{Y} 2$ through $\mathrm{Y} 1)$ is significant. This result showed that gender has an indirect effect on consumptive behavior through financial literacy. These findings reinforce the previous findings proving that gender differences affect the level of knowledge and financial understanding that ultimately affect one's behavior in making decisions related to consumption [4], [8], [11]. The findings of this research also reinforce Planned Behavior Theory that individual behavior is indirectly influenced by gender differences [6], [7].This study proved that male respondents have more knowledge and skill, and they also have higher confidence in making financial decisions than that of female respondents, which ultimately and indirectly affects them in making decisions related to their consumptive behavior.

\section{Relationship between Work Experience (X3), Financial Literacy (Y1), and Consumptive Behavior (Y2)}

The test results showed that the variable of work experience has a significant relationship with the variable of financial literacy (t-count $>$ t-table, $10.87<1.97$ Shown at Fig. 3). These findings reinforce the findings of previous studies conducted by Seyedian and Yi, and Hogan, et al [9], [10] showing that work experience has a relationship with financial literacy. The knowledge and ability in managing the finance of one who has worked will increase if compared to someone who has not worked.

The results of Sobel test we have done showed that there is a significant indirect effect of work experience on consumptive behavior through financial literacy (X3 $\rightarrow$ Y2 through Y1). These results once again support Planned Behavior Theory, which in this path, the test indicated that one's background experience, which in this study is a work experience, has an influence on one's consumptive behavior, mediated by financial literacy. This finding is certainly an indication that someone who has work experience (is working or has worked) will gain more experience in knowledge and skills in financial management (financial literacy) that will ultimately make them wiser in decision-making related to their consumption activities.

\section{Relationship between Academic Ability/IP (X3), Financial Literacy (Y1), and Consumptive Behavior (Y2)}

The test results showed that the variable of work experience has a significant relationship with the variable of financial literacy (t-count $>$ t-table, $2.34<1.97$ Shown at Fig. 3). These results support the previous research conducted by Sabri and Gudmunson [12] presenting that student's high academic ability is shown by the Achievement Index (IP), which reflects the student's knowledge and ability to learn. The findings of this study indicated that students who have a high academic ability will have a good level of understanding also on the concepts of finance, and vice versa.

The result of Sobel test also shows a significant indirect influence of academic ability on consumptive behavior through financial literacy variable $(\mathrm{X} 4 \rightarrow \mathrm{Y} 2$ through $\mathrm{Y} 1)$. These results reinforce the findings of Sabri and Gudmunson [12] mentioning that students with the high academic ability may have good understanding of financial concepts, and at the end they can apply their knowledge.

This study also shows us that the academic ability of students, which is reflected in the achievement index (IP), not only seen in the understanding of financial concepts, but also seen in the application of that understanding on consumption decision making.

\section{CONCLUSION}

The results of this study indicated a significant influence of gender, work experience and academic ability on financial literacy. These findings more strengthen the previous studies discussed in the background. In addition, the test results also found the significant indirect effects of gender, work experience and academic ability on consumptive behavior through financial literacy. However, this study failed to find a significant evidence of the influence of age on financial literacy as well as the indirect influence of age on consumptive behavior through financial literacy.

\section{REFERENCES}

[1] L. Lina and H. F. Rosyid, "Perilaku konsumtif berdasarkan locus of control pada remaja putri," Psikologika J. Pemikir. dan Penelit. Psikol., vol. 2, no. 4, pp. 5-14, 2017.

[2] I. Imawati, Susilaningsih, and E. Ivada, "Pengaruh Financial Literacy terhadap Perilaku Konsumtif Remaja pada Program IPS SMA Negeri 1 Surakarta Tahun Ajaran 2012/2013," J. Pendidik. Ekon., vol. 2, no. 1, pp. 48-58, 2013.

[3] H. Chen and R. P. Volpe, "An analysis of personal financial literacy among college students," Financ. Serv. Rev., vol. 7, no. 2, pp. 107--128, 1998.

[4] M. A. Hilgert, J. M. Hogarth, and S. G. Beverly, "Household Financial Management: The Connection between Knowledge and Behavior," Fed. Reserv. Bull., vol. 89, pp. 309-322, 2003.

[5] K. Chinen and H. Endo, "Effect of Attitude and Bacground on Personal Finance Ability: A Student Survey in the United State," Int. J. Manag., vol. 29, no. 1, pp. 33-45, 2012.

[6] J. R. Smith, D. J. Terry, A. S. Manstead, W. R. Louis, D. Kotterman, and J. Wolfs, "Interaction Effects in the Theory of Planned Behaviour: The interplay of Self-Identity and Past Behaviour," J. Appl. Soc. Psychol., vol. 37, no. 11, pp. 2726-2750, 2007. 
[7] L. Sommer, "The theory of planned behaviour and the impact of past behaviour," Int. Bus. \\& Econ. Res. J., vol. 10, no. 1, pp. 91-110, 2011.

[8] A. Ansong and M. A. Gyensare, "Determinants of university workingstudents' financial literacy at the University of Cape Coast, Ghana," Int. J. Bus. Manag., vol. 7, no. 9, pp. 126-133, 2012.

[9] M. Seyedian and T. D. Yi, "Improving financial literacy of college students: A cross-sectional analysis," Coll. Stud. J., vol. 45, no. 1, pp. 177-190, 2011.

[10] E. Hogan, S. Bryant, and L. Overymyer-Day, "Relationships between college students' credit card debt, undesirable academic behaviors and cognitions, and academic performance," Coll. Stud. J., vol. 47, no. 1, pp. 102-112, 2013.

[11] S. P. Wagland and S. Taylor, "When it comes to financial literacy, is gender really an issue?," Australas. Accounting, Bus. Financ. J., vol. 3 , no. 1, p. 3, 2009.

[12] M. Fazli Sabri, C. C. Cook, and C. G. Gudmunson, "Financial wellbeing of Malaysian college students," Asian Educ. Dev. Stud., vol. 1, no. 2, pp. 153-170, 2012. 